ISSN 0103-5150

Fisioter. Mov., Curitiba, v. 29, n. 1, p. 183-91, Jan./Mar. 2016

Licenciado sob uma Licença Creative Commons

DOI: http://dx.doi.org.10.1590/0103-5150.029.001.AR03

(c) (i)

\title{
Physical therapy in avoidable hospitalizations for primary care-sensitive conditions
}

\author{
Fisioterapia nas hospitalizações evitáveis por \\ condições sensíveis à atenção primária
}

\author{
Alessandra Bombarda Müller ${ }^{[a]}$, Nadia Cristina Valentini ${ }^{[b]}$, Maria Eugênia Bresolin Pinto ${ }^{[\mathrm{c}] *}$ \\ [a] Universidade Vale do Rio dos Sinos, (UNISINOS), São Leopoldo, RS, Brazil \\ [b] Universidade Federal do Rio Grande do Sul, (UFRGS), Porto Alegre, RS, Brazil \\ [c] Universidade Federal de Ciência da Saúde de Porto Alegre, (UFCSPA), Porto Alegre, RS, Brazil
}

\begin{abstract}
Avoidable hospitalizations for primary care-sensitive conditions have been used as indicators of access to timely and appropriate care because hospital admissions for many conditions could be prevented by interventions in primary care. Physical therapists play an important role in health promotion, disease prevention, and the pursuit of fairness and improvements in the effectiveness of health care services, which are the goals of the public policies proposed by the Brazilian unified health care system. We used MEDLINE and SciELO to search the literature for articles concerning the association between physical therapy and the reduction of avoidable hospitalizations for primary care-sensitive conditions. The literature on the topic is still in its infancy and confined to relatively few studies. Although the available literature associates access to quality primary care with reduced hospitalizations for primary care-sensitive conditions, there is a need for original studies investigating whether there is an association between physical therapy and decreased hospital admissions for primary care-sensitive conditions.
\end{abstract}

Keywords: Avoidable hospitalization. Ambulatory care-sensitive condition. Physical therapy.

*ABM: MSc, e-mail: abombarda@unisinos.br NCV: PhD, e-mail: nadiacv@esef.ufrgs,br MEBP: PhD, e-mail: eugenia@ufcspa.edu.br 
Resumo

As hospitalizações evitáveis por condições sensíveis à atenção primária têm sido utilizadas como indicadores de acesso à atenção oportuna e adequada, fundamentada na elevada capacidade de resolução por parte da atenção primária de determinados problemas de saúde. Nesse contexto, a atuação do fisioterapeuta faz parte deste processo, pois a promoção da saúde e a prevenção de doenças, assim como a busca de equidade e maior resolutividade dos atendimentos prestados - objetivos das políticas públicas preconizadas pelo sistema único de saúde no Brasil que definem as ações propostas para o acolhimento dos usuários - também estão compreendidas nas ações de fisioterapia. $O$ objetivo desta revisão foi verificar a associação da fisioterapia à redução de hospitalizações evitáveis por condições sensíveis à atenção primária, por meio de pesquisa e análise de artigos indexados na base de dados MEDLINE e na biblioteca virtual SciELO. Foi constatada escassa produção bibliográfica relacionada ao tema, ainda muito incipiente. Embora a revisão da literatura disponível associe o acesso à atenção primária de qualidade à redução de hospitalizações por condições sensíveis a essa modalidade de atenção, há a necessidade de estudos originais que verifiquem se existe ou não associação entre a atuação fisioterapêutica e a redução de hospitalizações por condições sensíveis à atenção primária.

Palavras-chave: Hospitalizações evitáveis. Condições sensíveis à atenção primária. Fisioterapia.

\section{Introduction}

Primary health care (PHC) is the health care model proposed by the World Health Organization (WHO), which recommends the provision of universal access to health promotion, disease prevention, diagnosis, treatment, rehabilitation and health maintenance (1). PHC serves as the individual's "gateway" to the Unified Health System (SUS) in Brazil. The SUS is a hierarchical system based on principles of universality, comprehensiveness and equity (2).

Studies conducted in recent years have highlighted the positive impact of health promotion and restoration activities on the Brazilian population, although the implementation and organization of comprehensive and continuous primary care to meet the demands and needs of distinct population groups is still associated with access difficulties and poor quality of services (3 - 6). Avoidable hospitalizations for primary care-sensitive conditions have been used as indicators of access to timely and appropriate care. They serve as a tool for the analysis of the impact and performance of PHC services, because hospital admissions for many conditions could be prevented by interventions in primary care. These interventions result in a reduction in hospital admissions, an increase in preventive measures, and higher quality of outpatient care (3 - 9).
Hospitalizations for ACSC could be prevented by effective interventions in primary care. The reduction of the risk of hospitalization can be achieved by promotion of health, prevention of diseases, early diagnosis and treatment of acute episodes, adequate control and monitoring of chronic diseases, and proper management of resources (3 - 9). For example, primary care interventions can help reduce the number of hospital admissions for preventable infectious diseases by implementing vaccination against measles, tetanus, diphtheria, etc.; providing immediate treatment for gastroenteritis and pneumonia; and reducing hospital admission, readmission and stay for acute complications of noncommunicable diseases (diabetes mellitus, hypertension and heart failure) (17).

Thus, individuals who seek primary care services and benefits from the resolution of their problem do not experience worsening of their condition and do not require hospitalization. Nevertheless, other factors may also interfere with this outcome: the manner in which health care teams organize their work; community's sociocultural determinants; strategic location for access to health care services; and lack of preparation for handling the situation that triggered the damage to health $(8,21-23)$.

The investigation of the causes of preventable hospitalizations for ACSC makes it possible to determine 
which risk factors are associated with those people who seek health care services. There is no global consensus on the choice of these diagnoses, because the list of ACSC changes according to the local reality or weather conditions of a given territory $(4,15)$. Because this indicator has been increasingly used in Brazil, in 2008 the Ministry of Health defined and published the Brazilian list of ACSC (Table 1) (24), taking into consideration the country's epidemiological profile and health system, and adapting the following criteria used in previous international studies: (1) existence of scientific evidence that the cause of hospitalization is a primary care-sensitive condition; (2) being an easily diagnosed condition; (3) being a health problem that affects much of the population (i.e., not being a rare event/condition); (4) being a condition that could have been prevented or solved by interventions in primary care; (5) need for hospitalization when the condition occurs; (6) diagnosis is not induced by financial incentives. (3) The Brazilian list comprises a larger number of infectious diseases, unlike foreign lists. This is due to the epidemiological characteristics of the country, where there is still a high prevalence of these diseases. (25)

Table 1 - List of Primary care-sensitive conditions

(To be continued)

\begin{tabular}{|c|c|}
\hline ICD-10 diagnosis & Code used \\
\hline $\begin{array}{l}\text { Diseases preventable by } \\
\text { immunization and sensitive } \\
\text { conditions }\end{array}$ & $\begin{array}{l}\text { A15.0 to A15.3; A15.4 to } \\
\text { A15.9; A16.0 to A16.2; } \\
\text { A16.3 to A16.9; A17.0; } \\
\text { A17.1 to A17.9; A18; A19; } \\
\text { A33 to A37; A51 to A53; } \\
\text { A95; B05; B06; B16; B26; } \\
\text { B50 to B54; G00.0; I00 to } \\
\text { I02 }\end{array}$ \\
\hline $\begin{array}{l}\text { Infectious gastroenteritis and } \\
\text { complications }\end{array}$ & A00 to A09; E86 \\
\hline Anemia & D50 \\
\hline Nutritional deficiencies & $\mathrm{E} 40$ to $\mathrm{E} 46 ; \mathrm{E} 50$ to $\mathrm{E} 64$ \\
\hline Ear, nose and throat infections & H66; J00 to J03; J06; J31 \\
\hline Bacterial pneumonia & $\begin{array}{l}\text { J13; J14; J15.3; J15.4; } \\
\text { J15.8; J15.9; J18.1 }\end{array}$ \\
\hline Asthma & $\mathrm{J} 45 ; \mathrm{J} 46$ \\
\hline Lung diseases & $\begin{array}{l}\text { J20; J21; J40; J41 to J44; } \\
\text { J47 }\end{array}$ \\
\hline
\end{tabular}

Table 1 - List of Primary care-sensitive conditions (Conclusion)

\begin{tabular}{ll}
\hline ICD-10 diagnosis & Code used \\
\hline Hypertension & I10; I11 \\
Angina & I20 \\
Heart failure & I50; J81 \\
Cerebrovascular diseases & G45; G46; I63 to I67; I69 \\
$\begin{array}{ll}\text { Diabetes Mellitus } & \text { E10.1; E10.1 to E10.9; } \\
& \text { E11.0; E11.1; E11.2 to } \\
& \text { E11.9; E12.0; E12.1; E12.2 } \\
\text { to E12.9; E13.0; E13.1; } & \text { E13.2 to E13.9; E14.0; } \\
& \text { E14.1; E14.2 to E14.9 } \\
& \text { G40; G41 } \\
\text { Epilepsies } & \text { N10 to N12; N30; N34; } \\
\text { Kidney and urinary tract } \\
\text { infections } \\
\text { Infections of the skin and }\end{array}$ \\
subcutaneous tissues \\
$\begin{array}{l}\text { Inflammatory disease of } \\
\text { related diseases }\end{array}$ & A46; L01 to L04; L08 \\
\hline Gastrointestinal ulcer & N70 to N73; N75; N76 \\
\hline
\end{tabular}

Note: Ordinance SAS/MS No. 221, of April 17, 2008.

Physical therapists play an important role in health promotion and disease prevention, as well as in the pursuit of fairness and improvements in the effectiveness of health care services - which are the goals of the public policies proposed by the Brazilian unified health care system to provide user embracement (26). The purpose of this literature review was to determine whether there is association between the use of physical therapy and the reduction of preventable hospitalizations for ACSC.

\section{Materials and Methods}

Literature review. We searched MEDLINE (accessed through PubMed) using the following keywords: "ambulatory care-sensitive conditions", "primary care-sensitive conditions", "primary health care", "physical therapy modalities" and "avoidable 
hospitalizations". In addition, we searched SciELO using following terms in Portuguese "avoidable hospitalizations", "physical therapy", "asthma", "hipertension", "diabetes mellitus", "cerebrovascular diseases" and "heart failure". Searches were conducted between September and December 2012. Due to the lack of studies associating Physical Therapy and ACSC, we also analyzed the references cited in the articles found, as well as the theses and dissertations related to the terms mentioned above, in order to investigate the type of assistance provided to this population. The final sample of this study was composed of studies on PHC characteristics associated with the risk of hospitalization for ACSC, and on physical therapy treatment of the noncommunicable chronic diseases (NCDs) listed above.

Most of the articles found on the topic of ACSC (10) were cross-sectional studies. Fourteen papers on health indicators were ecological studies. We also identified two systematic reviews and seven theses/dissertations. None of the papers analyzed the use of physical therapy in the prevention of avoidable hospitalizations for ACSC or NCDs such as asthma, hypertension, diabetes mellitus, cerebrovascular disease and heart failure.

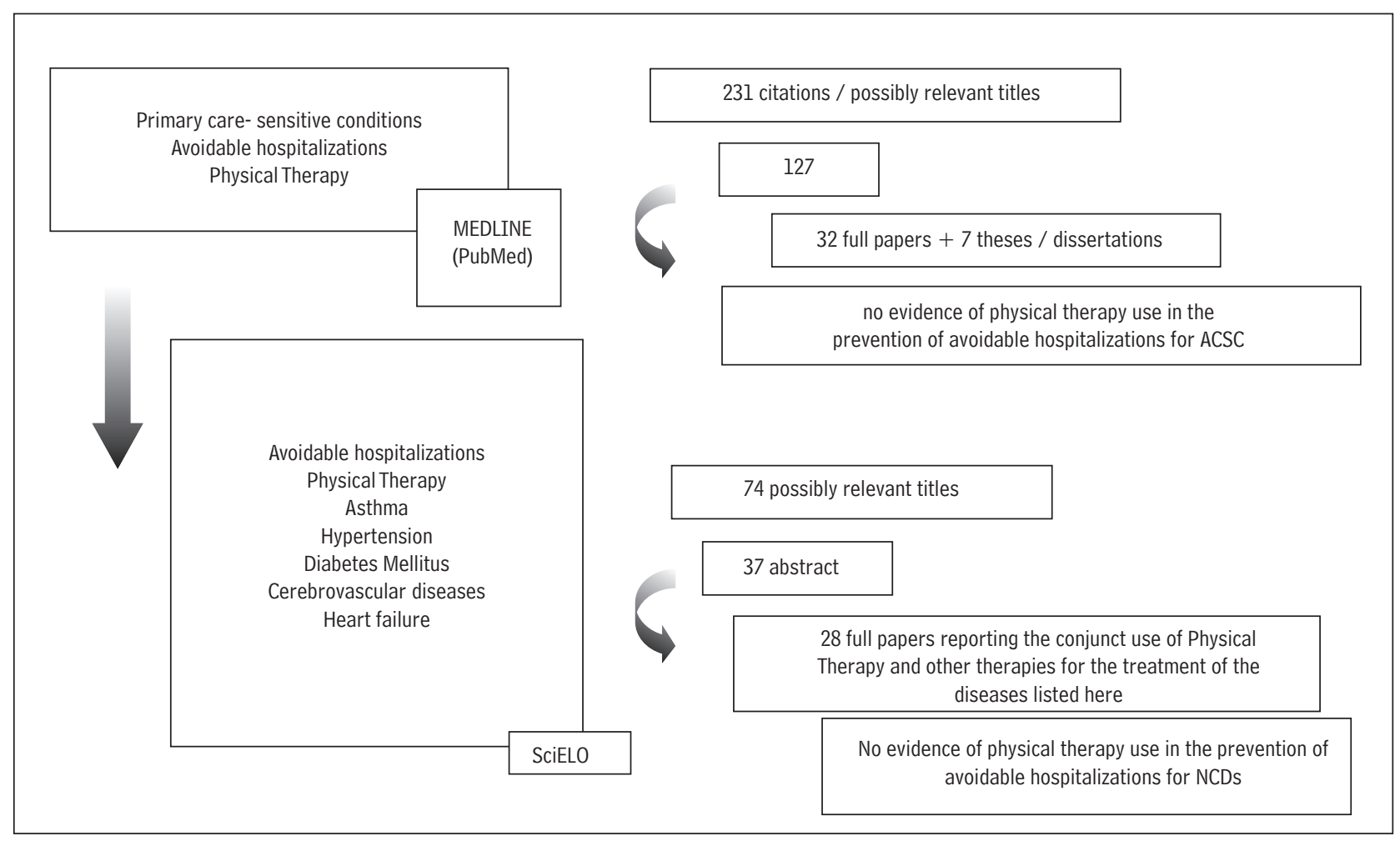

Figure 1- Flowchart of the methodology adopted.

\section{Discussion}

Hospitalizations for ACSC serve as a useful indicator for the Unified Health System (SUS). The idea behind this indicator is that hospitalizations for certain conditions reflect failures of the health system to provide access to quality primary care, because these conditions should have detected at a much earlier stage, which would have avoided the increase in their severity and/or prevented the onset of complications, thus eliminating the need for hospitalization (25). The definition of the Brazilian list of causes and the availability of data collected with software applications make it possible to use this indicator to develop studies on this topic, and implement specific actions to meet this care demand. This literature search, however, was hampered by the high variability of descriptors/keywords used to index the papers $(15,28)$.

International studies $(6,10,21$ - 23) indicate that admissions for ACSC are influenced by many different factors related to accessibility to care, such as socioeconomic status of the patient, organizational features of primary care, hospitalization criteria and supplemental health coverage. This is in line with the 
findings of national studies involving diagnoses of pneumonia and heart failure, for example $(4,11,17$, 21-23). Physical therapy plays a purely curative role in the treatment of these conditions. It helps avoid the worsening of these conditions and improve the quality of life of patients by aiding in the reestablishment of adequate kinetic/functional capacity.

Over the last years several international literature reviews on the topic have concluded that access to quality primary care reduces hospitalizations for conditions sensitive to primary care $(21-23,41)$. The results of national studies corroborate this estimate: the degree of coverage of Family Health Strategy (FHS) programs was associated with decreased hospitalizations rates for ACSC in general, as well as the hospitalizations rates for congestive heart failure and acute diarrhea in children under five years of age $(18,34,38)$. The increase in FHS programs was also associated with reduced length of stay of inpatients $(4,38)$. This corroborates the thesis that investments in PHC, in addition to other inherent benefits, have resulted in shorter hospital stays for $\operatorname{ACSC}(5,38)$.

According to the report of a survey conducted by the Ministry of Health until 2012, between 1999 and 2007 , hospitalizations of younger and older adults for ACSC accounted for $30 \%$ of hospital admissions in Brazil (43). In the period of the study, there was a $24 \%$ reduction in the rate of hospitalizations for ACSC and a 9\% reduction in the rate of hospitalizations for conditions unrelated to primary care. This study shows a direct relationship between investments in PHC and decreased hospitalization rates for ACSC (43).

The Mafra research (2010), which was conducted throughout the country, demonstrates that in 2007 hospitalizations for ACSC accounted for $27.44 \%$ of all hospitalizations, excluding deliveries (38). When comparing the evolution of admissions for ACSC and for other health problems, the study indicates a sharper reduction of the first. While the number of hospitalizations for ACSC decreased by around $19 \%$ in the period of the study, admissions for other reasons decreased by $8.5 \%$. This fact is consistent with the thesis that associates the decline in hospital admissions with increase in the provision of primary care services, which effectively took place in Brazil during the period analyzed $(4,12,14,15,20,25)$.

Other studies have indicated a downward trend in hospitalization rates for ACSC: Perpetual and Wong (2006), based on data from 1998 to 2004, have identified this trend in the state of Minas Gerais (38); Rehen and Egry (2009) report a reduction in the frequency of hospitalizations for ACSC in the state of São Paulo between 2000 and 2007 (8, 9); Dias da Costa et al (2010) have also identified a decrease in hospital admission rates for ACSC in the state of Rio Grande do Sul after 2001 (7, 13).

There are many possibilities for the use of physical therapy in ACSC and these represent an important contribution for the different levels of health care, directly and indirectly, both for the promotion of health and prevention of diseases, and in rehabilitation processes $(39,40,44)$. The provision of accessible and effective primary care avoids hospitalizations. Physical therapists can help minimize uncontrolled complications caused by a chronic disease, and facilitate access to preventive health services.

Actions for the prevention of conditions listed as health care quality indicators can all be implemented by multidisciplinary teams. These actions range from the provision of information and education about: the importance of vaccination for the prevention of diseases and of keeping the vaccination status up to date; changes in behavior to avoid viral and bacterial infections; signs and symptoms for the detection of the most prevalent diseases in the community; and what to do in emergency situations As evidenced in the study conducted by Mobley and colleagues (6) in 2006 , the increased availability of physical therapists in primary care was associated with lower hospitalization rates among older adults in the United States. Teamwork was also associated with a lower probability of ACSC diagnosis among inpatients in Bagé, RS (14). This implies a decentralization of health care provision from physicians to other health care providers. As a consequence, there is a more comprehensive approach to the disease process, which allows its better resolution by the multidisciplinary team.

Working with human movement, its object of study, Physical therapy can have a positive impact on risk factors for noncommunicable diseases. This could be achieved, for example, by encouraging patients to avoid sedentary behaviors, as the risk of cerebrovascular diseases and high blood pressureand diabetes-related diseases is associated, among other factors, with the absence of physical activities.

Much can be done to help spread the word about methods and means of exerting physical activity, body practices and movement therapies in PHC settings. It is important to involve different sectors of 
the community, such as neighborhood associations, schools, churches, NGOs and universities. Patients with risk factors for cerebrovascular diseases in particular could be instructed by health professionals about all the opportunities for physical activity: at work (stretching, postural changes), during transportation (walk to work or to the supermarkt whenever possible), during the performance of domestic chores and during leisure time (sports and recreation). Because chronically ill patients are at high risk for further stroke, they should receive higher priority and individual, customized interventions, for example. These individuals need to be more frequently and closely monitored, and they should also receive treatment to rehabilitate eventual cognitive, behavioral, speech, motor or sensory sequelae. The fundamental goal of a rehabilitation program (either outpatient or at home) is to help patients adapt to their disabilities, facilitate their functional recovery, and promote social, professional and familiar reintegration.

In addition, in the context of non-drug treatments in particular, physical therapists working in the FHS can create strategies to encourage and promote the practice of physical activity by patients with hypertension, diabetes, obesity, sedentary lifestyles, dyslipidemia, as this is a fundamental element in the care and monitoring of patients at risk of cerebrovascular accident (42).

With regard to the management of lung diseases and their progression, especially asthma, physical therapists can also intervene at an individual or collective level by implementing activities and programs that take into consideration social, economic, cultural and environmental aspects involved in care. They should act not only in the treatment of asthma attacks, but also be a key player in the education for the prevention of new episodes by providing proper guidance and instructions about the maintenance of an airy atmosphere. These measures could result in better quality of life and lower morbidity. Frequent hospitalizations for asthma are associated with elevated morbidity and represent an important public health problem. Inadequate control of the disease has led to an increase in the number of emergency room visits, hospitalizations and deaths. Despite the unfavorable scenario, health programs offering an appropriate diagnostic and therapeutic approach for patients, as well as educational activities and rehabilitation measures, have succeeded in reducing hospitalizations for asthma attacks $(44,45)$. The provision of education programs in conjunction with drug therapy represents one of the pillars of success in these programs, and have shown to help reduce disease exacerbation, hospitalizations for asthma, and costs of disease (46).

\section{Final Considerations}

In addition to its impact on the reduction of hospitalizations for primary care sensitive conditions, quality primary care delivery might also influence the decrease in length of stay of inpatients and the amount of hospital readmissions. As a result of the above, another desirable effect is the reduction of public costs for hospitalizations, either because of avoided hospitalizations or of anticipated discharges.

Thus, it is important to quantify the benefits that could be brought about by the expansion of primary care - both for the reduction in the length of hospital stay and of the costs associated with it. The use of physical therapy in primary care requires an adjustment of this care modality to the reality of PHC and to the needs of the population. There is a wide range of possibilities for its qualified participation. The investigation of the epidemiological profile of the population, its environmental conditions, and the prevalence of morbidity in patients seen in PHC help in the planning of health education activities and in the development of appropriate physical therapy strategies.

As the literature on the topic is still in its infancy and confined to relatively few studies, there is a need for original studies investigating whether there is an association between physical therapy and decreased hospital admissions for primary care-sensitive conditions. The disclosure of this information may help in the planning and evaluation of health care services, by providing diagnostic and therapeutic resources based on the use of physical therapy. Physical therapy can make a greater contribution to this recent and incipient topic. Physical therapists play an important role in this process, especially by helping in the development and implementantion of activities and practices that are associated with the resolution of primary care-sensitive conditions.

\section{References}

1. World Health Organization. [Cited in 20/10/2012]. Available from: http://www.who.int/publications. 
2. SUS. [Cited in 20/10/2012]. Available from: http:// portalsaude.saude.gov.br/portalsaude/area/313/ legislacao.html.

3. Alfradique ME, Bonolo PF, Dourado I, Lima-Costa MF, Macinko J, Mendonça CS, Oliveira VB, Sampaio LFR, Simoni CD. Ambulatory care sensitive hospitalizations: elaboration of Brazilian list as a tool for measuring health system performance (Project ICSAP-Brazil). Cad Saúde Pública. 2009;25(6):1337-49.

4. Fernandes VBL, Caldeira AP, Faria AA, Rodrigues Neto JF. Hospitalizations sensitive to primary care as an evaluation indicator for the Family Health Strategy. Rev Saúde Pública. 2009;43(6):928-36.

5. Campos AZ, Theme-Filha MM. Hospitalization for primary care sensitive conditions in Campo Grande, Mato Grosso do Sul State, Brazil, 2000-2009. Cad Saúde Pública. 2012;28(5):845-55.

6. Mobley LR, Root E, Anselin L, Lozano-Garcia N, Koschinsky J. Spatial analysis of ederly Access to primary care services. Int J Health Geograph. 2006;5:19.

7. Dias da Costa JS, Büttenbender DC, Hoefel AL, Souza LL. Hospitalization for primary care sensitive conditions in municipalities with full local health management control in Rio Grande do Sul State, Brazil. Cad Saúde Pública 2010;26(2):358-64.

8. Rehem TCMSB, Egry EY. Internment for conditions suitable for primary health care in São Paulo State. Ciência e Saúde Coletiva 2011;16(12):4755-66.

9. Torres RL, Rehem TCMSB, Egry EY, Ciosak SI. The panorama of ambulatory care sensitive conditions in district of São Paulo. Rev Esc Enferm USP 2011;45(2):1661-6.

10. Manns BJ, Tonelli M, Zhang J, Campbell DJT, Sargious P, Ayyalasomayajula B, Clement F, Johnson JA, Laupacis A, Lewanczuk R, McBrien K, Hemmelgam BR. Enrolment in primary care networks: impact on outcomes and processes of care for patients with diabetes. CMAJ 2012;184(2):144-52.

11. Batista SRR, Jardim PCBV, Sousa ALL, Salgado CM. Hospitalizations due to primary care sensitive cardiovascular conditions in municipalities of Central-West Brazil. Rev Saúde Pública 2012;46(1):34-42.
12. Boing AF, Vicenzi RB, Magajewski F, Boing AC, Moretti-Pires RO, Peres KG, Lindnen SR, Peres MA. Reduction of ambulatory care sensitive conditions in Brazil between 1998 and 2009. Rev Saúde Pública 2012;46(2):359-66.

13. Dias-da-Costa JS, Borba LG, Pinho MN, Chatkin M. Quality of primary care measure by preventable hospitalizations in the South of Brazil. Cad Saúde Pública 2008;24(7):1699-1707.

14. Nedel FB, Facchini LA, Martin-Mateo M, Vieira LAS, Thumé E. Family health program and ambulatory care sensitive conditions in Southern Brazil. Rev Saúde Pública 2008;42(6):1041-52.

15. Nedel FB, Facchini LA, Martin-Mateo M, Navarro A. Primary health care risk factors for hospitalization for ambulatory care sensitive conditions: systematic literature review. Epidemiol Serv Saúde 2010;19(1):61-75.

16. Laditka JN, Laditka SB. Insurance status and access to primary health care: disparate outcomes for potentially preventable hospitalization. J Health Soc Policy 2004;19(2):81-100.

17. Caminal HJ, Starfield B, Sanchez RE, Hermosilla PE, Martin MM. La atencion primaria de salud y las hospitalizaciones por ambulatory care sensitive conditions en Cataluna. Revista Clinica Española 2001;201(9):501-7.

18. Oliveira BRG, Vieira CS, Collet N, Lima RAG. Causes of hospitalization in the National Healthcare System of children aged zero to four in Brazil. Rev Bras Epidemiol 2010;13(2):268-77.

19. Chang CF, Pope RA. Potentially avoidable hospitalizations in Tennessee: analysis of prevalence disparities associated with gender, race and insurance. Public Health Rep 2009;124(1):127-37.

20. Giovanella L, Mendonça MHM, Almeida PF, Escorel S, Senna MCM, Fausto MCR, Delgado MM, Andrade CLT, Cunha MS, Martins MIC, Teixeira CP. Family health: limits and possibilities for an integral primary healthcare approach in Brazil. Ciência e Saúde Coletiva 2009;14(3):783-94. 
21. Bermúdez-Tamayo C, Márquez-Calderón S, Aguila MMR, López PME, Espinosa JO. Características organizativas de la atencíon primaria y hospitalización por lós principales ambulatory care sensitive conditions. Aten Primaria 2004;33(6):305-11.

22. Caminal HJ, Morales EM, Sánchez RE, Cubells LMJ, Bustins PM. Hospitalizaciones prevenibles mediante uma atención primaria oportuna y efectiva. Aten Primaria 2003;31(1):6-17.

23. Falik M, Needleman J, Herbert R, Wells B, Politzer R, Benedict MB. Comparative effectiveness of health centers as regular source of care: applications of sentinel ACSC events as performance measures. J Ambul Care Manage. 2006;29(1):24-35.

24. BRASIL. Ministério da Saúde. Secretaria de Atenção à Saúde. Departamento de Atenção Básica. PORTARIA NO. 221 DE 17 DE ABRIL DE 2008.

25. Dourado I. Trends in primary health care sensitive conditions in Brazil: the role of the family health program (Project ICSAP-Brazil) Medical Care. 2011;49(6):577-84.

26. BRASIL. Ministério da Saúde. Saúde da Família nos Territórios da Cidadania. Entrevista sobre internações por condições sensíveis à atenção primária. Rev Brasileira Saúde da Família. 2008;9(18):4-6.

27. Elias E, Magajewski F. Primary health care in the south of Santa Catarina: analysis of admissions for ambulatory care sensitive conditions in the 1999-2004 period. Rev Bras Epidemiol. 2008;11(4):633-47.

28. Harzheim E, Stein AT, Álvarez-Dardet C. The effectiveness of child primary health care. Boletim da Saúde. 2004;18(1):23-40.

29. Caldeira AP, Fernandes VBL, Fonseca WP, Faria AA. Admissions to pediatric hospital for conditions amenable to primary care in Montes Claros, Minas Gerais, Brazil. Rev Bras Saúde Matern Infant. 2011;11(1):61-71.

30. Leal RCAC, Braile DM, Souza DRS, Batigália F. Assistance model for patients with asthma in the primary care. Rev Assoc Med Bras. 2011;57(6):697-701.

31. Silva AAM, Gomes UA, Tonial SR, Silva RA. Risk factors for hospitalization of children aged one to four years in São Luís, Maranhão, Brazil. Cad Saúde Pública. 1999;15(4):749-57.
32. Oliveira RR, Costa JR, Mathias TAF. Hospitalization of children under five years of age for avoidable causes. Rev Latino-Am Enferm. 2012;20(1):1-8.

33. Portes LH. Ações voltadas para o tabagismo: análise de implementação e perfil das internações por condições sensíveis à atenção ambulatorial tabaco-relacionadas no município de Juiz de Fora/MG. [Dissertation] - Universidade Federal de Juiz de Fora, Juiz de Fora, 2012.

34. Lima SCCA. Internações hospitalares de crianças por condições sensíveis à atenção primária à saúde: estudo de tendência temporal em Pernambuco. [Dissertation] Universidade Federal da Bahia, Salvador, 2012.

35. Rehem TCMSB. Internações sensíveis à atenção primária: limites e possibilidades da lista brasileira de diagnósticos. [Thesis] - Universidade de São Paulo, São Paulo, 2011.

36. Jeremias MS. Internações hospitalares por condições sensíveis à atenção primária em Lages (SC), Brasil. [Dissertation] Universidade Federal de Pelotas, Pelotas, 2010 .

37. Nedel FB. Internações hospitalares evitáveis pela atenção primária: estudo do impacto do programa Saúde da Família sobre as internações por condições sensíveis à atenção primária no Rio Grande do Sul, Brasil. [Thesis]. Universidade Federal de Pelotas, Pelotas, 2009.

38. Mafra F. O impacto da atenção básica em saúde em indicadores de internação hospitalar no Brasil. [Dissertation]. Universidade de Brasília, Brasília, 2010.

39. Rezende M, Moreira MR, Amancio Filho A, Tavares MFL. A equipe multiprofissional da Saúde da Família: uma reflexão sobre o papel do fisioterapeuta. Ciência Saúde Coletiva [online] 2009;14(1):1403-10.

40. Almeida ALJ, Guimarães RB. O lugar social do fisioterapeuta brasileiro. Fisioterapia e Pesquisa [online] 2009;16(1):82-8.

41. Shou-Hsia C, Chi-Chen C, Yen-Fei H. A longitudinal examination of continuity of care and avoidable hospitalization evidence from a universal coverage health care system. Arch Intern Med 2010;170(18):1671-7.

42. Pimenta CP. Prevenção das doenças cerebrovasculares no Brasil, no âmbito da atenção primária à saúde. [Thesis] - Universidade do Estado do Rio de Janeiro, Rio de Janeiro, 2009. 
43. Oliveira VB, Turci MA, Lima e Costa MFF, Bonolo PF. Avaliação do impacto das ações do Programa de Saúde da Família na redução das internações hospitalares por condições sensíveis à atenção básica em adultos e idosos. Relatório final de pesquisa. Belo Horizonte, março de 2012.

44. Brandão HV, Cruz CMS, Santos Júnior IS, Ponte EV, Guimarães A, Cruz AA. Hospitalizações por asma: impacto de um programa de controle de asma e rinite alérgica em Feira de Santana (BA). J Bras Pneumol 2009;35(8).

45. Cruz AA, Moreira E, Brandão HV, Santos Júnior IS. Programa de controle da asma e rinite alérgica de Feira de Santana. In: Cerci Neto A, editor. Asma em Saúde Pública. Barueri: Manole; 2007. p.133-9.
46. Lasmar LM, Calazans GC, Fontes MJ, Camargos PA. Programa criança que chia - Belo Horizonte - MG: Experiência mineira com um programa municipal de atendimento a criança asmática. In: Cerci Neto A, editor. Asma em Saúde Pública. Barueri: Manole; 2007. p. 93-101.

Recebido: 06/11/2013

Received: 11/06/2013

Aprovado: 19/06/2015

Approved: 06/19/2015 
